\title{
Resistensi Musisi Independen terhadap Komodifikasi dan Industrialisasi Musik di Indonesia
}

\section{Nurly Meilinda ${ }^{1^{*}}$, Caesar Giovanni², Nunik Triana3 dan Syanaz Lutfina4}

\author{
${ }^{1}$ Program Studi Ilmu Komunikasi, FISIP Universitas Sriwijaya, Sumatera Selatan, Indonesia. \\ E-mail: nurlyml@gmail.com \\ 2Program Pasca Sarjana Departemen Ilmu Komunikasi Universitas Indonesia, DKI Jakarta, \\ Indonesia. E-mail: caesargiovanni@gmail.com \\ 3Program Pasca Sarjana Departemen Ilmu Komunikasi Universitas Indonesia, DKI Jakarta, \\ Indonesia. E-mail: triana.nunik@gmail.com \\ 4Program Pasca Sarjana Departemen Ilmu Komunikasi Universitas Indonesia, DKI Jakarta, \\ Indonesia. E-mail: syanazluthfina@gmail.com \\ ${ }^{*}$ Penulis Korespondensi
}

\section{Article Info}

Article History

Received 19 Jan 2021

Revised 16 Aug 2021

Accepted 15 Sept 2021

\section{Keywords:}

Adorno, commodity, critic, popular music, standardization.

\section{Kata kunci:}

Adorno, kritik, komoditas, musik populer, standarisasi.
Abstract: This paper will review the development of the music industry in Indonesia by holding Theodor Adorno's criticism of the culture industry, especially the music industry. This paper tries to analyse whether Adorno's criticism of the popular music is still relevant to describe the current condition of the Indonesian music industry and explain how the existing political and economic conditions affected it. This paper began with explanatory approach which explained the development of the Indonesian music industry. Data collected from the articles in mass and online media, we also conduct an interview with one group of musician called orchest stamboel. The results showed that Adorno's critics about how music becomes a commodity are still relevant to be used in understanding most of the case in Indonesian music industry, but cannot represent the characteristics of all Indonesian musician. This is because although most music in Indonesia is used as the main tool of capitalism in gaining profit, on the other hand, there is also a variety of music with unique genres performed by the musicians that are not following the logics and characteristics of popular music that presented by Adorno, which is: standardization, interchangeable, and pseudoindividualism.

\begin{abstract}
Abstrak: Riset ini menganalisis relevansi kritik Adorno terhadap musik populer di Indonesia dengan melihat konteks ekonomi politik yang mengitarinya. Penelitian menggunakan pendekatan kualitatif dengan strategi kasus. Adapun yang menjadi kasus grup musik Orchest Stamboel. Data dikumpulkan melalui wawancara dan artikel yang dipublikasikan melalui media massa dan online. Hasil penelitian menunjukkan bahwa kritik Adorno tentang bagaimana musik menjadi komoditas masih relevan untuk digunakan dalam memahami sebagian besar kasus di industri musik Indonesia, tetapi belum dapat merepresentasikan karakteristik semua musisi Indonesia. Ini karena walaupun kebanyakan musik di Indonesia dijadikan sebagai alat utama untuk memperoleh keuntungan, tapi di sisi lain terdapat pula ragam musik dengan genre unik yang dibawakan oleh para musisi yang tidak mengikuti logika dan ciri khas musik populer seperti yang dikemukakan oleh Adorno, yaitu: standarisasi, interchangeable, dan pseudoindividualism.
\end{abstract}




\section{PENDAHULUAN}

Adorno (1941) dikenal secara luas sebagai salah satu kritikus terkemuka budaya populer, yang menurutnya merupakan bentuk kebudayaan yang rendah, bersifat homogen sehingga menciptakan seniman dan masyarakat yang pasif dan tunduk kepada pemilik modal. Pendapat Adorno, khususnya mengenai industri musik dan musik populer, bisa dilihat pada esai yang ditulisnya, terutama "The Fetish Character of Music and the Regression of Listening (1938), On Popular Music (1941), dan On Jazz (1939). Target Adorno adalah musik hits yang mainstream, band swing jazz, musik klasik yang ringan, dan musik film. Menurut Adorno (1941), yang paling fundamental adalah standarisasi. Menurutnya, lagu-lagu populer memiliki bentuk yang standar dan bagian yang dapat dipertukarkan (interchangeable). Bentuk standar yang dimaksud, misalnya, aturan bahwa sebuah lagu dalam paduan suara harus terdiri dari berapa oktaf dan berapa not. Lagu juga harus memiliki komponen seperti intro, chorus/reff, serta outro dalam urutan yang kurang lebih mirip. Jenis- jenis hit juga mengikuti pola yang kaku dan mudah dipahami, serta memiliki karakter seperti lagu ibu, lagu rumah, lagu omong kosong, pseudo-nursery rhymes, dan ratapan akan gadis/kekasih yang hilang. Artinya, semua lagu mengarahkan kembali ke pengalaman yang sama dan tidak punya 'novelty' untuk diperkenalkan kepada pendengar (Adorno, 1976).

Horkheimer dan Adorno (2002) menjelaskan 'standarisasi' ini juga dalam situasi dimana industri musik diarahkan untuk memaksimalkan profit. Ini akan membentuk karakteristik utama dari lagulagu yang akan dibuat. Lagu harus dibuat familiar, dan pada dasarnya mirip dengan lagu yang sudah populer sebelumnya sehingga pendengar tidak bingung dan jadi menyukai lagu baru ini seperti mereka menyukai lagu sebelumnya. Namun, lagu juga tidak boleh identik dengan lagu sebelumnya karena pendengar menjadi tidak tertarik untuk membelinya. Kesamaan setiap lagu juga harus disembunyikan dengan menggunakan detil 'pseudo-individuating' yang akan membuat setiap lagu terlihat unik padahal hanya superfisial saja (Stone, 2016). Pseudo-individual ini akan berpengaruh pada kepatuhan kita terhadap struktur dalam lagu yang bisa merusak kapasitas 'mendengar' seseorang. Pendengar jadi tidak terdorong untuk terlibat dalam pendengaran struktural (structural hearing) dengan berpegang pada elemenelemen musik yang akan semakin terbuka ketika menyimak sebuah musik (Adorno, 1976). Alih-alih, pendengar hanya akan bereaksi pada detail pseudo-individualnya saja tanpa terlibat dalam keseluruhan evolusi lagu tersebut karena memang tidak ada yang perlu diperhatikan. Dalam kondisi ini, seseorang menjadi bereaksi pada level sensori murni, yang bergantung pada apakah detail lagu tersebut bisa menyenangkan atau tidak. Jadi, 'mendengarkan' bagi kita, merosot ke level primitif, seperti anak-anak, yaitu tanpa berpikir (Adorno \& Horkheimer, 2002).

Adorno memandang musik pop sebagai "perekat sosial" karena musik pop menawarkan relaksasi dari pekerjaaan yang bisa disimak tanpa harus diperhatikan. Kaum kapitalis menanamkan hal tersebut kepada masyarakatnya sebagai sesuatu yang dibutuhkan karena musik pop seolah menawarkan khayalan, kebahagiaan, resolusi dan rekonsiliasi di dalam kehidupan. Kenikmatan yang ditawarkan musik pop tersebut membuat orang berhenti berpikir tentang realitas kehidupan yang keras dan hambar dari 
sebuah masyarakat kapitalis (Strinati, 2007).

Genre populer dikarakterisasikan oleh suara yang lembut dan menenangkan, harus mudah dipahami dan enak didengar dengan tujuan menarik kaum kelas menengah yang mencari ketenangan melalui musik (Fuchs, 2016). Musik seperti ini identik sebagai musik mall atau cosmopolitan karena lagu-lagu ini dimainkan di mall dengan tujuan untuk meredam suara bising dari jalanan sehingga memungkinkan orang untuk belanja di mall dalam menjalankan gaya hidup konsumerismenya. Ini yang disebut Adorno dengan musik yang menjadi komoditas.

Kritik Adorno terhadap industri budaya sesungguhnya bukan kritik terhadap bentuk kreativitas dan ekspresi budaya, melainkan terhadap bentuk komoditas (commodity form). Adorno menentang segala bentuk komoditas dan yakin bahwa dimanapun itu berada, budaya komoditas ini akan merusak kehidupan manusia di masyarakat. Adorno tidak membenci budaya populer, tapi ia membenci bentuk komoditas dalam setiap kebudayaan. Dalam kaitannya dengan musik, Adorno menulis bahwa peran musik dalam proses sosial secara eksklusif adalah sebagai komoditas, sehingga pengaturannya akan jatuh ke tangan monopoli yang kuat (Fuchs, 2016). Apa yang disebut Adorno sebagai fetisisme musikal bisa dilihat dalam penggunaan berbagai macam musik pada iklan yang sifatnya komersial. Ini juga berdampak pada efek dari musik-musik ini kepada pendengar yang menjadi tidak signifikan lagi.

Dalam esai Adorno, On Popular Music (1941), musik dibagi ke dalam dua jenis, yaitu musik serius dan musik populer. Ringkasnya bagi Adorno, pada musik serius (Beethoven, et al), "the detail virtually contains the whole and leads to the exposition of the whole, while, at the same time, it is produced out of the conception of the whole". Artinya, musik serius itu adalah sebuah keutuhan, diproduksi dari sebuah proses dalam konsep yang sama, yaitu keutuhan. Sebaliknya, pada musik populer, hubungan yang timbul dan utuh itu muncul dari ketidaksengajaan, detailnya tidak berhubungan dengan suatu keutuhan sehingga berakibat pada detail musik yang tidak beraturan, tidak bisa dikembangkan, dan tidak memiliki kekuatan untuk mempengaruhi. Adorno menggarisbawahi tiga konsep besar dalam musik populer, yaitu standarisasi, interchangeable, dan pseudo-individualism. Ketiga konsep inilah yang kemudian akan dijadikan sebagai standpoint dalam memahami industri budaya saat ini. Selain itu, tulisan ini juga menambahkan konsepsi interchangeable yang juga disinggung Adorno dalam tulisannya, walaupun konsep ini tidak dituliskan dalam sub bahasan khusus dalam esai Adorno seperti standarisasi dan pseudo-individualism. Dari deskripsi kritik Adorno ini, maka poin-poin utama yang digarisbawahi tentang musik dalam kajian ini adalah: standarisasi, interchangeable, dan pseudo-individualism. Pandangan Adorno inilah yang kemudian akan dijadikan standpoint dalam memahami musik sebagai industri budaya di Indonesia dalam paper ini.

Pemikiran Adorno akan industri budaya tidak sedikit juga mendapatkan kritik dari beberapa kalangan. Dua kritik yang akan kami paparkan sebagai bagian dari penelitian ini adalah bahwa Adorno tidak pernah mendefinisikan dan menganalisis gagasan otentisitas dengan jelas dalam karyanya (Paddison, 2004). Kedua bahwa kritik Adorno terhadap Jazz digerakkan oleh sikap rasisnya terhadap orang kulit hitam. Namun, kedua kritik ini kemudian dibantah dan dijelaskan dengan 
merujuk pada karya-karya Adorno, misalnya, dalam Philosophie on New Music (terjemahan dari Philosophie der neuen Musik oleh Robert Hullot- Kentor, 2006), otentisitas belum menjadi konsep kunci yang digunakan Adorno dalam membahas karya Schoenberg dan Stravinsky karena otentisitas dipahami sebagai "being-so-and-not-being-able-tobe-otherwise".

Otentisitas bagi Adorno

diasosiasikan dengan modernis, hubungan yang tidak sama antara individu dan sosial, struktur internal dari karya seni dan kondisi eksternal yang berfungsi di dalamnya. Sebuah hubungan yang menghubungkan derajat tinggi dari kesadaran diri dan refleksivitas diri terhadap karya seni dalam level yang teknis. Sebaliknya, inauthenticity/inotentisitas adalah gagasan dimana kerja tidak diinternalisasi dalam hubungan yang tidak sama ini, tidak merefleksi diri, dan tetap patuh dengan stereotip tradisional, atau yang disebut adorno dengan resigned art. Untuk jadi otentik, harus tampil dengan menggunakan instrumen original dengan nada/tuning orisinal, dan menggunakan riset sejarah untuk memproduksi suara sama ketika musik itu sedang diciptakan, atau setidaknya sesuai dengan maksud dari si pengarang lagu. Adorno mencontohkan kematian Bach atas kritiknya ini. Menurutnya, musik Bach kemudian dinaikkan/diubah oleh sejarawan dalam prinsip abstrak yang mentransendensi subjektivitas individual sehingga menutup kemungkinan untuk musik ini kemudian dapat dipahami bagaimana partisipasinya sebagai pencerahan pada zamannya.

Dalam mengkritik musik Jazz, Adorno juga bukan digerakkan oleh sikap rasisnya terhadap orang kulit hitam, tetapi lebih digerakkan oleh konsistensi pemikirannya yang kritis. Berangkat dari konsep sentral dalam estetika bagi Adorno seperti dikutip dari tulisan Lee B. Brown tentang Popular Culture: Adorno's Critique The Case of Jazz Music pada jurnal Aesthetic Educations (1992). Dikatakan bahwa estetika adalah otonomi yang berarti bahwa fungsi seni bersifat non fungsional. Seni adalah suatu bidang yang autentik dan imanen yang tidak dapat dijelaskan dengan referensi untuk tujuan, misalnya, lembaga politik, agama, atau ekonomi. Bagi Adorno, jazz juga merupakan komoditas karena produksi musik ini sama singkatnya dengan gaya musiman dalam arti orang menolak gaya jazz yang ketinggalan zaman sebagai hal yang tidak keren sama halnya seperti menolak mode pakaian. Di sisi lain, cukup aneh jika menganggap Adorno, yang lahir dari keluarga Yahudi dan harus melarikan diri dari Nazi Jerman, adalah seorang yang rasis. Dalam artikel On Jazz, dia mengkritik karakter komersial dari jazz sebagai komoditas massal yang berjuang untuk meningkatkan pemasarannya dan menunjukkan karakter komoditasnya (Fuchs, 2016). Nazi melarang jazz dan musik lainnya ditampilkan oleh orang kulit hitam, mereka menganggap itu bisa menurunkan nilai seni. Penilaian Adorno dalam hal ini memang problematik, tapi tidak rasis.

Berbagai macam studi mengenai budaya populer dalam industri musik khususnya di Indonesia telah banyak dilakukan oleh sarjana di bidang Ilmu Komunikasi. Beberapa penelitian yang terkait, misalnya, penelitian Yuliarti (2011) yang berjudul "Lagu dan Penanaman Nilai Sosial". Penelitian dengan kultivasi ini mengkategorikan lagu berdasarkan nilainilai hubungan romantis, yaitu kelompok lagu abu-abu yang mengandung nilai romantis dan penyimpangannya dan kelompok lagu hitam, yaitu lagu yang hanya mengandung penyimpangan dari nilai hubungan romantis, misalnya, selingkuh, kekasih gelap, dan lain-lain. 
Penelitian Yuliarti (2011) ini lebih fokus pada bagaimana terpaan media dalam hal ini lagu-lagu cinta yang kemudian membentuk realitas subjektif pendengarnya dalam melihat hubungan romantis mereka.

Penelitian lainnya yang membahas topik yang serupa adalah penelitian Khadavi (2014) yang menggunakan metode dekonstruksi Derrida untuk membaca teks-teks pada industri budaya terkait dengan musik pop. Penelitian ini menunjukkan bahwa musik pop Indonesia saat ini terpolarisasi menjadi dua bagian, yaitu major label yang berorientasi pada keuntungan dan indie label yang berorientasi pada kreatifitas dan kebebasan. Penelitian ini juga menyimpulkan bahwa Gerakan Indie merupakan sebuah alternatif dalam upaya dekonstruksi terhadap teks industri budaya dengan memberi nuansa yang baru pada genre musik pop yang menjadi kebutuhan masyarakat.

Penelitian Yuliarti (2015) juga mengulas mengenai nilai cinta dalam lagu serta mengelaborasi kesenjangan dan memberi rekomendasi terkait dengan kesenjangan tersebut. Penelitian ini juga memaparkan isi lagu pop Indonesia yang dilihat dari lirik/teks lagu. Penulis menunjukkan bahwa sering kali nilai yang dikandung dalam pesan media massa tidak sejalan dengan nilai positif yang ideal dan seharusnya terjadi pada kehidupan sosial antar manusia, dan bahwa seharusnya lagu dapat memberikan pesan positif yang mampu meningkatkan kualitas hidup masyarakat Indonesia misalnya dengan memuat juga pesan moral dan spiritual dalam lagu populer. Penelitian ini belum menunjukkan secara kritis maksud dari lagu yang sesuai dengan realitas objektif.

Dari penelitian yang pernah dilakukan tersebut, belum ada yang menggunakan Adorno untuk melakukan kritik atas industri musik. Oleh karena itu, penelitian ini menawarkan kebaruan pada lokus penelitian dan pada perspektif kajian media dan budaya popular yang digunakan. Selain itu, berbeda dengan penelitian sebelumnya yang lebih banyak fokus pada analisis isi lagu dan lirik, penelitian ini menggunakan metode studi kasus dengan berfokus pada salah satu kelompok musik indie yang berkaya di industri musik Indonesia. Dengan begitu, ada analisis yang mendalam terutama terkait dengan perlawanan musik indie.

Penelitian ini tidak hanya fokus pada musik sebagai fenomena komunikasi massa, melainkan melihat pada kelompok dan komunitas musik yang memproduksi, mengemas, serta mendistribusi konten musik mereka. Dengan begitu, penelitian diharapkan akan memberikan sumbangan yang sangat berarti bagi kajian-kajian musik di Indonesia, utamanya musik indie yang belum banyak dikaji. Pertimbangan menggunakan Adorno karena Ia adalah salah satu pemikir yang termasuk dalam Mahzab Frankfurt yang memiliki konsepkonsep utama pemikiran yang unik dibandingkan dengan mazhab pragmatisme yang populer di Amerika Serikat, terutama untuk bidang komunikasi.

\section{METODE}

Penelitian ini merupakan penelitian kualitatif yang menggunakan metode studi kasus untuk menganalisis kejadian atau situasi serta memberikan penekanan pada analisis kasus dengan hanya menggunakan salah satu contoh kasus. Adapun subjek dalam penelitian ini adalah grup musik Orchest Stamboel yang menjadi contoh kasus dalam melihat industri musik Indonesia sebagai industri budaya.

Pemilihan Orchest Stamboel dalam penelitian ini karena grup musik ini merupakan salah satu grup yang mengawali karir melalui jalur 
independent. Selain itu, grup ini secara sadar menolak logika pasar dalam proses kreasi musik mereka. Adapun instrumen pengumpulan data yang digunakan dalam penelitian ini adalah wawancara semi terstruktur karena memungkinkan komunikasi yang lebih baik selama proses pengumpulan data. Wawancara dilakukan melalui telepon dan email kepada seluruh personil Orchest Stamboel. Selain melalui wawancara, penelitian ini juga melakukan studi literatur dengan menelusuri artikel terkait yang diterbitkan di media massa, terutama media massa online yang berguna dalam menambahkan rincian spesifik lainnya dalam mendukung informasi dari sumber-sumber lainnya.

Analisis data dilakukan dengan menggunakan studi kasus melalui pengamatan dari media massa dan dari wawancara dengan subjek penelitian, guna menyajikan uraian menyeluruh dari apa yang coba diamati dalam penelitian, yang dalam hal ini adalah resistensi musisi independent terhadap budaya popular dalam industri musik Indonesia.

\section{HASIL DAN PEMBAHASAN Orchest Stamboel dalam Industri Musik Indonesia}

Musik populer berubah

karakteristiknya seiring dengan perubahan iklim lingkungannya. Musik populer beradaptasi dengan kebutuhan zaman dan harapan dari "sebuah kaum", yang mana pada akhirnya akan membantu kaum ini mengatasi hambatan-hambatan zaman, membantu menyampaikan opini atau posisi mereka di masyarakat, dan bahkan bisa membantu kaum ini untuk menjalankan latihan berdemokrasi (Weintraub, 2006). Kaum yang dimaksud dalam kutipan ini merujuk pada kelompok yang memegang kekuasaan dalam praktik industri musik, termasuk di Indonesia meskipun orientasi musik Indonesia mengarah pada tujuan profit. Menilik tangga lagu Billboard Indonesia, yang diunggah 8 April 2020, musik di Indonesia masih didominasi oleh musik pop (Kusumapradja, 2020) seperti lagu "Pura Pura Lupa" yang di nyanyikan oleh Mahen di posisi pertama, disusul berurutan dua lagu yang dinyanyikan oleh Andmesh, yaitu "Kumau Dia" di posisi ke-2 dan "Nyaman" di posisi ke-3, "Sedang Sayangsayangnya" di posisi ke-4 oleh Mawar De Jongh, serta "Hanya Rindu" di posisi ke-5 yang kembali dibawakan oleh Andmesh.

Sebelumnya, di penghujung 2019, Google merilis 9 lagu yang paling banyak dicari orang Indonesia melalui situs pencarian Google. Hanya tiga di antaranya dinyanyikan oleh musisi Indonesia dan berbahasa Indonesia, yakni "Celengan Rindu" milik Fiersa Besari, "Hanya Rindu" milik Andmesh Kamaleng serta "Kemarin" milik grup band Seventeen (Situmorang, 2019). Dari lagu-lagu tersebut, terlihat bahwa musik pop dengan tema personal khususnya cinta masih mendominasi selera pasar Indonesia. Tema ini pun tidak mengalami perubahan dalam 4 (empat) dasawarsa terakhir. Setidaknya, sejak 80an, sekitar 94.6 persen lirik lagu pop Indonesia adalah tema personal, dan sisanya 5.4 persen bercerita tentang tema sosial (Ashaf, 2003). Dominasi lagu-lagu cinta yang serupa ini bisa menunjukkan arah orientasi musik di Indonesia yang bertujuan keuntungan. Bahkan, jika merujuk pada deretan lagu yang paling diminati di atas, terdapat empat lagu dari satu musisi yang sama, dengan warna musik yang mirip. Kesepuluh lagu yang masuk dalam lagu terfavorit di Indonesia ini memenuhi kriteria lagu populer yang disebutkan oleh Adorno dan beberapa ahli lainnya yaitu lagu yang enak didengar, mudah dipahami, seolah unik walaupun sebenarnya keunikannya hanya superfisial, dan juga tidak mendorong pendengarnya untuk mendengar secara struktural (Shapiro, 2011). 
Terdapat kelompok-kelompok subkultural yang mengungkapkan diri mereka melalui musik dengan menggunakan gaya-gaya khas seperti yang diasosiasikan dengan hip-hop, grunge, punk, reggae, dan heavy metal, misalnya. Mereka sering terbentuk, berkembang dan naik daun bersama zaman secara politik. Ini berlaku pada era hippis ketika musik protes menjadi sebuah senjata ideologis utama dalam pertarungan politik dan budaya yang berkecamuk pada waktu itu (Lull, 1998). Dalam konteks di Indonesia, meski industri musik didominasi oleh musik beraliran pop, tidak semua musisi lantas beraliran pop demi memenuhi selera pasar. Beberapa musisi di Indonesia membuktikan bahwa mereka mampu bertahan dari godaan untuk menciptakan karya yang seragam dan tunduk pada selera pasar. Musisi-musisi inilah yang akan dibahas sebagai faktor yang dapat membatalkan pemiskinan industri budaya dalam bidang musik. Adapun beberapa musisi, misalnya, Iwan Fals, karena berhasil sukses dan digemari dengan lirik yang kritis dan tidak biasa. Selain Iwan Fals, terdapat juga Efek Rumah Kaca, dan dalam penelitian ini Orchest Stamboel.

Kelompok musik Orchest Stamboel memberikan corak berbeda dalam industri musik. Terbentuk sejak 2014, kelompok musik yang terdiri atas Adnan Nanda (gitar dan vokal), Hanafi Lamusu (bass dan vokal), serta Edwin Harahap (drums dan vokal) ini mengusung genre indorock dengan fokus musik instrumental yang mengedepankan harmonisasi gitar. Indorock adalah genre musik yang populer di Eropa terutama Belanda dan Jerman pada awal 1960-an. Salah satu Pioner dari genre musik ini adalah The Tielman Brothers.

Melalui wawancara via email, gitaris Orchest Stamboel, Adnan Nanda atau bisa disapa Nanda, mengatakan istilah musik indorock tidak dikenal hingga 1980-an.
Para musisi ekspatriat memainkan musik ini di panggung-panggung reuni di Belanda. Pada masa keemasan era 1960an, jenis musik ini lebih akrab disebut rock $n$ roll saja, tidak ada istilah indorock yang mengacu ke jenis musik tertentu sehingga dapat dikatakan indorock bahwa rock $n$ roll dengan gaya bermain orang-orang keturunan Indonesia di Eropa. Namun, indorock tetap berbeda dengan musik rock $n$ roll ala Amerika. Pada musik indorock, nuansa Indonesia seperti gamelan atau keroncong kerap digunakan oleh gitaris indorock.

Orchest Stamboel memandang hal ini sebagai sesuatu yang unik, dan oleh karenanya mereka fokus memilih genre musik ini. Alasan lain, menurut Nanda, indorock dipilih sekaligus sebagai bentuk apresiasi terhadap musisi-musisi dari timur yang kala itu mampu bersaing berebut pamor dengan musisi-musisi Eropa. Terkait dengan selera pasar, menurut Nanda, Orchest Stamboel tidak membebani diri mereka untuk menjadikan indorock sebagai musik yang akrab di telinga pendengar musik Indonesia, khususnya anak-anak muda saat ini.

\section{"Kami tidak memiliki target khusus akan seperti apa Orchest Stamboel berterima di masyarakat, seberapa besar fanbase, atau sebanyak apa keuntungan yang dihasilkan. Orchest Stamboel murni proyek idealis yang kami jalankan semata karena apresiasi terhadap Indorock itu sendiri" (Nanda, Wawancara, 8 April 2020).}

Bagi kelompok musik ini, pendengar musik Orchest Stamboel adalah refleksi karena jawaban paling jujur dari karya musik adalah pendengar. Bagaimana sebuah band ingin dicitrakan, dapat terlihat dari apresiasi pendengarnya. Pendengar Orchest Stamboel yang kebanyakan berasal dari Eropa terutama Belanda dengan kisaran usia tidak muda 
dikatakan Nanda sudah mampu membuat mereka senang apalagi saat ini mulai banyak kaum muda di Jakarta yang mulai menyukai indorock. Nanda memandang hal ini sebagai titik yang baik, walau mereka tidak memiliki keinginan yang tinggi untuk membuat semua kaum muda menoleh kepada indorock. Mereka pun menyadari dari awal kemunculannya, indorock memang tidak menuai popularitas di Indonesia. Tujuan Orchest Stamboel hanya ingin menjadi kelompok musik yang melanjutkan tradisi memainkan musik indorock karena rasa kebanggaan memainkan musik-musik rock $n$ roll yang dibawakan oleh keturunan Indonesia di Eropa pada masa lalu. Bagi mereka musik adalah salah satu sarana aktualisasi diri.

"kadang jual CD biasanya hanya laku paling banyak lima keping. Maklum, cakram digital musik kami diimpor langsung dari Belanda, dan harga jual per satuannya sekira Rp.30o ribu. Bayangkan, siapa yang mau membeli cakram digital musik sebuah band baru tak dikenal, dengan harga empat kali lipat dari harga cakram digital musik band indie lokal pada umumnya?" (Nanda, Wawancara, 8 April 2020).

Terkait dengan keuntungan, Nanda mengatakan mereka tidak mementingkan hal itu karena merilis sebuah album di Eropa sudah menjadi pencapaian yang positif dan membanggakan. Menurutnya, apa yang Orchest Stamboel kerjakan bersumber dan bermuara pada keyakinan bahwa melalui musik mereka bisa memberikan sesuatu yang dapat didengarkan, dinikmati, dikenang, kepada khalayak dimanapun mereka berada.

Nanda tidak memungkiri keuntungan atau uang diperlukan Orchest Stamboel agar dapat tetap eksis, tetapi ia juga tidak memaksakan biaya untuk keperluan band harus diambil dari keuntungan yang dihasilkan dari karya mereka. Untuk biaya hidup, para personil Orchest Stamboel mencarinya dengan cara bekerja di luar Orchest Stamboel seperti Nanda yang saat ini berprofesi sebagai wartawan. Fakta ini menunjukkan realita dalam industri musik Indonesia bahwa memang tidak seluruh musisi yang melawan selera pasar dalam karyanya bisa bertahan secara finansial jika hanya mengharapkan pada karya musiknya. Namun, semangat dan konsistensi Orchest Stamboel ini untuk tetap berkarya di dunia musik, dan menciptakan musik yang mencerahkan menunjukkan bahwa seniman dapat terus menghasilkan karya tanpa semata didorong motif ekonomi. Jika seniman-seniman yang satu visi dengan Orchest Stamboel terus konsisten dengan karyanya, maka tentu akan memberikan tambahan preferensi pada penikmat musik tanah air dan bukan tidak mungkin akan menyadarkan mereka akan pentingnya lagu-lagu yang bukan hanya menceritakan keluh kesah hubungan percintaan, tapi juga turut menyuarakan isu-isu sosial dan budaya.

\section{Relevansi Kritik Adorno terhadap Industri Musik Indonesia}

Dengan melihat perkembangan musik di Indonesia dan kondisi musik Indonesia saat ini, terlihat bagaimana relevansi kritik Adorno terhadap industri budaya dengan fenomena yang ada di masyarakat Indonesia. Budaya pop merupakan produk masyarakat industrial, dimana kegiatan pemaknaan dan hasilnya (yaitu kebudayaan) dihasilkan dan ditampilkan dalam jumlah besar, kerap dengan bantuan teknologi produksi, distribusi, dan penggandaan massal supaya lebih mudah dijangkau masyarakat luas (Heryanto, 2002). Model ini berlaku juga untuk musik Indonesia yang pada 1950-an, yang berkat penolakan keras Presiden Soekarno terhadap musik-musik 
Amerika justru memaksa musisi-musisi Indonesia untuk berkarya sehingga tercipta aliran Lenso yang ikut mewarnai perkembangan industri musik di Indonesia. Industri musik Indonesia kembali beradaptasi dengan kebutuhan dan selera masyarakat. Pada 1980-an, konser dan festival mulai tumbuh yang berujung pada lahirnya grup musik dari berbagai genre yang mewarnai musik Indonesia, seperti Kahitna, Krakatau, atau pada genre pop modern ada Chrisye, Keenan Nasution, Fariz RM, dan di genre pop misalnya Iwan Fals, Doel Sumbang, serta Ebiet G. Ade.

Tidak berhenti sampai di sini, popularitas musisi mainstream ini semakin berkembang dengan basis penggemar yang luas di Indonesia. Sejak 2000, musik pop mutakhir mencapai sukses penjualan yang tidak pernah dibayangkan di tahun-tahun sebelumnya. Peterpan bukanlah yang pertama dan satusatunya, sebut saja Nidji, Ungu, D’Masiv, Kerispatih, dan bahkan untuk semakin melanggengkan nilai komersial dari lagulagu populer berkembang juga musikmusik yang hanya mengandalkan satu lagu hit saja seperti Vagetoz, Merpati, Hijau Daun, Wali, dan Kangen Band. Artinya lagu di setiap era mungkin punya tipe yang berbeda namun sebenarnya sama, musik populer terus berkembang namun dengan pola yang sama. Maka, tidak mengherankan jika kita menyimak lagulagu yang saat ini beredar di ruang dengar dan atau diputar di ruang publik, maka akan menemukan lagu-lagu yang memiliki formula kurang lebih sama satu sama lain, terutama lagu dari perusahaan label rekaman major. Unsur-unsur lagu, seperti nada, durasi, dan topik yang dibahas masih serupa yaitu lagu tentang jatuh cinta, patah hati atau selingkuh. Kita juga akan mendapatkan komposer yang ikut perform di acara-acara komersial di televisi yang bersifat profit-oriented, atau bahkan dipakai untuk iklan produk dagang. Dengan kata lain, karya-karya musik populer saat ini berusaha memenuhi standarnya dan bisa saling menggantikan dengan tujuan agar lagu-lagu ini menjadi populer dan mampu menghasilkan keuntungan dalam jumlah besar.

Adapun beberapa tahun ke belakang, muncul karya-karya musisi Indonesia yang terlihat baru dan dibawakan oleh penyanyi-penyanyi populer dengan nada elegan seperti Raisa, Isyana Sarasvati, Yura Yunita, Petra Sihombing, Rendy Pandugo, Ardhito Pramono, dan lain-lain. Walaupun begitu, musik yang mereka mainkan juga memiliki pola dan karakter yang kurang lebih sama. Jadi, pendengar seolah-olah memiliki individualisme dan kekuatan dalam menentukan pilihan dari sekian banyak pilihan musik yang bisa didengarkan, walaupun sebenarnya perbedaannya tidak begitu signifikan. Artinya, ada detail pseudo-individualism yang ikut dibawa oleh industri musik Indonesia saat ini. Deskripsi di atas menunjukkan bahwa apa yang dikatakan Adorno masih relevan untuk memahami fenomena industri musik Indonesia saat ini. Musik populer adalah musik yang memiliki standarisasi, bisa dipertukarkan, serta berorientasi profit. Walaupun begitu, kenyataan bahwa masih ada banyak seniman yang berkarya dengan tidak memenuhi kriteria populer yang disebutkan Adorno tidak bisa diabaikan.

Iwan Fals dan Efek Rumah Kaca adalah contoh dari sekian banyak musisi yang tidak memenuhi kriteria populer Adorno, tetapi ternyata mampu diterima dengan sangat baik oleh masyarakat Indonesia. Bahkan, penjualan musik serta tiket konsernya dapat dikatakan luar biasa. Fenomena ini menunjukkan bahwa masyarakat saat ini sudah memiliki pengetahuan dan preferensi musik yang lebih bervariasi, ketertarikan akan musik yang mencerahkan juga sudah tampak 
pada masyarakat walaupun masih banyak juga musik yang seragam dan sesuai dengan kriteria populer Adorno beredar di masyarakat. Perlu dipertimbangkan juga, musisi-musisi dari jalur independen yang berkarya bukan hanya dengan pertimbangan profit, melainkan untuk membuat karya seni berupa lagu berkualitas, misalnya, Orchest Stamboel. Musisi yang bergerak di jalur ini biasanya menolak untuk mengikuti logika pasar walaupun dengan resiko hanya mendapat sedikit atau bahkan tidak mendapatkan keuntungan dari karya mereka sehingga mengharuskan mereka untuk punya pekerjaan di luar seni dan atau berkarya di dua jalur yaitu musik populer dan musik serius. Selain itu, menarik didiskusikan jika melihat fakta bahwa garis pemisah antara bentuk superior dan inferior dalam musik sudah menjadi semakin tidak terlihat terutama di tahun-tahun belakangan ini. Dalam hal ini, musik dangdut bisa jadi contoh yang baik karena ia sudah bertransformasi dari tipe musik yang dimainkan di perkampungan, kemudian setelah 'diperindah' dan 'dibersihkan' lalu dipromosikan oleh media nasional berubah menjadi musik yang menargetkan kaum kelas atas dan dimainkan di kafe dan klub di kota. Sebaliknya, musik yang posisinya dinilai setidaknya berada di atas lagu dangdut, bisa juga dinyanyikan dengan gaya dangdut untuk menyesuaikan selera kelas bawah. Misalnya, lagu musisi korea Black Pink yang di-aransmen dengan musik koplo dan dinyanyikan oleh Via Vallen.

Naik kelasnya campursari yang ditampilkan dengan tema orkestra, dan turun kelasnya lagu-lagu yang dinyanyikan Via Vallen secara koplo adalah beberapa contoh kasus yang menarik untuk dipahami dengan menggunakan standpoint kritik terhadap Adorno. Herbert Gans (1974), misalnya, mengatakan bahwa sesungguhnya tidak ada pembedaan antara high culture dan low culture, melainkan perbedaan yang ada adalah dikarenakan oleh perbedaan standar estetika, yang terkait kelas sosioekonomi. Ini semua adalah masalah selera sehingga bukan masalah suatu kultur kesenian lebih baik dari yang lain, melainkan perbedaan itu hanyalah persoalan perbedaan standar estetika (taste culture) yang dipengaruhi oleh kelas sosioekonomi. Menurut Gans, ini adalah hal yang baik karena mendekatkan hasil karya seni ke semua kalangan. Kontrasnya, situasi dalam industri musik Indonesia ini menunjukkan bahwa industri budaya ini memiliki variasi dan dinamika yang amat beragam sehingga tidak mungkin untuk kemudian dipahami melalui satu perspektif saja. Meskipun demikian, pandangan Adorno benar mengenai keseragaman dan orientasi keuntungan atas industri budaya, tetapi tidak bisa juga diabikan bahwa industri budaya juga menghasilkan beragam inovasi dalam kesenian yang sifatnya juga baik bagi masyarakat.

Beberapa ahli lain juga menawarkan perspektif dalam melihat musik sebagai industry budaya. Walter Benjamin menyebutkan istilah reproduksi mekanik kesenian (mechanical reproduction of art) yang merujuk pada keadaan dimana karya seni bisa direproduksi, digandakan, disajikan dalam berbagai bentuk, serta didistribusikan ke berbagai tempat yang berujung pada hilangnya otoritas dan otentisitas, atau yang disebut Benjamin sebagai "aura". Ia juga mengatakan bahwa "the presence in time and space" akan menghilang dari karya tersebut. Meskipun demikian, berbeda dengan Adorno, ia mengatakan bahwa reproduksi mekanik masih memiliki elemen emansipatoris, artinya ia percaya bahwa melalui industri budaya, justru inovasi akan muncul dalam kesenian, selain itu model reproduksi mekanik ini juga mampu menghilangkan 
ketergantungan karya seni kepada ritusritus yang justru menghalangi karya seni untuk bisa dinikmati oleh masyarakat.

Kritik Gans (1974) memang lebih mudah diterima dengan logika industri budaya saat ini. Entitas dalam industri budaya terlalu beragam dengan kekhasannya masing-masing. Oleh karena itu, industri budaya tidak dapat dianalisis dengan satu perspektif saja, tetapi tidak berarti bahwa pendapat Adorno menjadi sama sekali tidak relevan dalam memahami industri kebudayaan. Pendapat Adorno akan karya seni dan industri kebudayaan mungkin tidak bisa digunakan secara utuh dalam menjelaskan situasi dan kondisi saat ini, namun di beberapa kasus masih sangat relevan untuk dijadikan landasan dalam berpikir, khususnya dalam menganalisis. Kritik pemikiran Adorno sangat diperlukan untuk menawarkan perspektif yang berbeda bagi para sarjana kajian budaya dalam memahami serta menjelaskan fenomena-fenomena yang terjadi dalam dinamika kehidupan masyarakat.

\section{KESIMPULAN}

Perkembangan musik Indonesia dari periode ke periode memang telah menghantarkan musik pada industri. Dimulai dengan berubahnya Lokananta yang awalnya perusahaan rekaman milik pemerintah dengan tugas utama pendokumentasian program $R R I$ menjadi perusahaan negara pada 1961 karena melihat peluang pasar pada industri musik dan akhirnya terjun langsung ke dalam industri. Hingga saat ini, musik aliran pop dengan tema personal, khususnya cinta, masih mendominasi selera pasar Indonesia. Tema ini memang tidak mengalami perubahan. Namun, tidak semua musisi lantas beraliran pop demi memenuhi selera pasar untuk meraih keuntungan. Beberapa musisi yang tetap teguh dengan alirannya sendiri dan tidak mementingkan selera pasar adalah Iwan Fals, Efek Rumah Kaca, serta Orchest Stamboel yang masing-masing memiliki tingkat kesuksesan berbeda di masyarakat.

Dapat disimpulkan, kritik Adorno yang mengatakan bahwa musik adalah komoditas masih cukup relevan untuk digunakan dalam memahami industri musik Indonesia. Namun, hal ini tidak merepresentasikan karakteristik semua musisi di Indonesia. Ini karena meskipun kebanyakan musik di Indonesia dijadikan sebagai alat utama mengumpulkan kapital, tetapi muncul juga beragam musik dengan genre unik yang dibawakan oleh musisi dengan karya yang tidak sesuai dengan karakteristik yang dipaparkan oleh Adorno, yaitu: standarisasi, interchangeable, serta memiliki efek pseudo- individualism. Penelitian ini menyarankan perlunya untuk merefleksikan kembali, yaitu bahwa pemikiran kritis perlu tetap dipertahankan dalam menikmati sebuah karya seni, agar masyarakat tidak terlena begitu saja dengan permasalahan personal yang sering dibahas dalam lagu populer, misalnya, patah hati, kebahagiaan dengan pasangan, melainkan diperlukan juga karya-karya musik yang dapat melatih dan meningkatkan sensibilitas manusia terhadap isu-isu sosial yang muncul dalam masyarakat. 


\section{DAFTAR PUSTAKA}

Adorno, Theodor W. ; Horkheimer, M. (2002). Dialectic of Enlightenment. Stanford University Press.

Adorno, T. W. (1941). On popular music. Studies in Philosophy and Social Science, 9(n/a).

Adorno, T. W. (1976). Introduction to the sociology of music. In Seabury Press.

Ashaf, A. F. (2003). Tema-tema dominan dalam musik Indonesia. Mediator: Jurnal Komunikasi, 4(2). https://doi.org/https://doi.org/10.29 313/mediator.v4i2.1025

Fuchs, C. (2016). Critical theory of communication: New reading of Lukacs, Adorno, Marcuse, Honneth, and Habermas in the age of internet. In University of Westminister Press. University of Westminister Press. http://www.uwestminsterpress.co.uk /site/books/10.16997/book1/

Heryanto, A. (2002). Budaya populer di Indonesia: Mencairnya identitas pasca orde baru. In Jalasutra.

Horkheimer, M., \& Adorno, T. W. (2002). Dialectic of enlightenment philosophical fragments. In G. S. Noerr (Ed.), Stanford University Press. Stanford University Press. https://www.sup.org/books/title/?id $=1103$

Khadavi, M. J. (2014). Dekonstruksi musik pop Indonesia dalam perspektif industri budaya. Jurnal Humanity, 9(2), 11310.

https://ejournal.umm.ac.id/index.ph p/humanity/article/view/2392

Kusumapradja, A. (2020). Billboard Indonesia top 10o. Billboardid.Com.

Lull, J. (1998). Media, komunikasi, kebudayaan: Suatu pendekatan global. In Yayasan Obor Indonesia.
Paddison, M. (2004). Authenticity and Failure in Adorno's Aesthetics of Music. In T. Huhn (Ed.). Cambridge Companions to Philosophy, 198-221.

Shapiro, J. J. (2011). Adorno's praxis of individuation through music listening. Música Em Perspectiva, $3(2)$.

https://doi.org/10.5380/mp.v3i2.219 80

Situmorang, R. T. (2019). 9 lagu paling banyak di cari orang Indonesia di Google sepanjang 2019. Bisnis.Com. https://lifestyle.bisnis.com/read/201 91212/254/1180629/9-lagu-palingbanyak-dicari-orang-indonesia-digoogle-sepanjang-2019

Stone, A. (2016). The value of popular music. In Palgrave Macmillan.

Strinati, D. (2007). Popular culture: Pengantar menuju teori budaya populer. In Bentang.

Weintraub, A. N. (2006). "The People" in Indonesia Popular Music; Dangdut Studies. Asian Journal of Communication, 16(4).

Yuliarti, M. S. (2011). Lagu dan penanaman nilai sosial (Studi kultivasi lagu-lagu pop Indonesia era tahun 2000-an terhadap pembentukan realitas subjektif mengenai nilai-nilai romantic relationship di kalangan mahasiswa jurusan ilmu komunikasi FISIP UNS). In UNIVERSITAS SEBELAS MARET. UNIVERSITAS SEBELAS MARET.

Yuliarti, M. S. (2015). Komunikasi musik: Pesan nilai-nilai cinta dalam lagu Indonesia. Jurnal ILMU KOMUNIKASI, 12(2). https://doi.org/10.24002/jik.v12i2.4 70 